\title{
LEVELS OF IMMUNOGLOBULINS OF ISOTYPE IgG AND IgG2 IN SUBJECTS LACKING FORMATION OF IgG ANTIBODIES AGAINST LIPOPOLYSACCHARIDE OF CHLAMYDIA*
}

\author{
Zuzana Medkováa, Petr Hejnar ${ }^{b^{*}}$ \\ a Immunology Division, Bio-Plus Laboratories, 63900 Brno, Czech Republic \\ b Institute of Microbiology, Faculty of Medicine, Palacký University, 77515 Olomouc, Czech Republic, e-mail: \\ hejnar@fnol.cz
}

Received: May 25, 2003; Accepted in revised form June 25, 2003

Key words: Chlamydia / Lipopolysaccharide / Antibodies / IgG / IgG2

In some patients with antibodies against LPS antigen of Chlamydia, specific immunoglobulins G are not present. The findings of isolated anti-LPS IgA/IgM antibodies are to be considered as possibly non-specifically or "false" positive. The aim of this study was to investigate if there is any difference in the level of total immunoglobulins of isotypes IgG and IgG2 in probands with isolated positivity anti-LPS IgA (i.e. without simultaneous presence of specific $\operatorname{IgG} ; \mathrm{n}=34$ ) as compared with a control group of subjects presenting positive anti-LPS IgA and IgG antibodies $(\mathrm{n}=44)$. Antibodies against LPS antigen of Chlamydia were determined by ELISA method ("Chlamydien-rELISA", medac, Germany). Total immunoglobulin levels were determined by nephelometry using the following kits: "Immunoglobulin G Reagent, ARRAY Systems", Beckman Coulter, USA and "Human IgG2 Subclass Beckman ARRAY Kits", The Binding Site, UK. The measured values were related to the age-dependent laboratory standard values and the differences between the tested groups were statistically evaluated $\left(\chi^{2}\right.$ test). Decreased total IgG have been demonstrated in $4(11.8 \%)$ probands and in $5(11.4 \%)$ subjects of the control group; increased total IgG were found in $2(5.9 \%)$ probands and in $1(2.3 \%)$ subject of the control group. Decreased levels of total IgG2 were not determined in any proband and were found in $1(2.3 \%)$ subject of the control group. Increased levels of IgG2 were registered in $12(35.3 \%)$ probands and in $15(34.1 \%)$ control subjects. No statistically significant differences were found between the two groups. It can be concluded that no relationship was proved between the levels of total $\mathrm{IgG}$ and $\mathrm{IgG} 2$ and the absence of formation of specific anti-Chlamydia-LPS IgG. Further research will be necessary for the elucidation of this phenomenon (e.g. the presence of specific anti-LPS IgG in immunocomplexes).

\section{INTRODUCTION}

Detection of antibodies against chlamydial genusspecific lipopolysaccharide antigen (LPS) is a test method, which is frequently used in indirect diagnostics of chlamydial infections. Evaluation of the course of the infection and of its treatment results is often based on monitoring the presence and the dynamics of antibody production. The activity of chlamydial infection is generally determined from IgA and IgM levels. Immunoglobulins of $\operatorname{IgA}$ isotype are typical both for the acute phases of primary infections and for the chronic and recurrent infections ${ }^{1-3}$. IgM antibodies occur particularly during the acute phases of primary infections and then they disappear, but their prolonged persistence has also been recorded in chronic, persisting infections ${ }^{1-5}$. Isolated occurrence of $\mathrm{IgG}$ isotype is usually interpreted as formerly experienced chlamydial infections (anam- nestic antibodies), but permanently high levels of $\mathrm{IgG}$ may indicate an active disease in chronic phase ${ }^{3-5}$.

Generally, first IgM isotype antibodies occur within 1 to 2 weeks after primary infection and then, in a short time interval, IgA will increase together with or soon followed by $\mathrm{IgG}^{6}$. Some individuals do not show the typical succession of antibody formation - examples of long-lasting presence of $\operatorname{IgM}$ without $\operatorname{IgA}$ evidence ${ }^{4,7}$ and $\operatorname{IgM}$ and / or IgA without IgG evidence ${ }^{8}$ are known. The positivity found only in IgA and / or IgM (without IgG evidence) can be considered as suspicious ("false" or "non-specific" positivity). Often the subsequent test does not prove any presence of chlamydial antibodies and the patient is seronegative.

The aim of the present study is to find out, whether there is any variation in level of total immunoglobulins of $\mathrm{IgG}$ and $\mathrm{IgG} 2$ isotypes in subjects with isolated positivity of specific IgA against chlamydial LPS (i.e.

\footnotetext{
* This study was presented at the 54. Tagung der Deutschen Gesellschaft für Hygiene und Mikrobiologie, Heidelberg, Germany, 6.-10. 10. 2002.
} 
without concurrent presence of specific $\mathrm{IgG}$ ) compared to a control group of persons with concurrent positive $\operatorname{IgA}$ and $\operatorname{IgG}$ against chlamydial LPS.

\section{PATIENTS AND METHODS}

The study group comprised 34 patients of the Teaching Hospital of Olomouc (women: 21, men: 13, age range: $1-86$ years, average age: 41.6 years) requested by their attending physicians to undergo the Chlamydia antibody assay.

The control group comprised 44 patients of the same hospital (women: 27, men: 17, age range: 6-84 years, average age: 43.8 years).

Anti-Chlamydia-LPS IgA alone were demonstrated in patients of the study group, while both anti-Chlamydia-LPS IgA and $\mathrm{IgG}$ were demonstrated in those of the control group. Regarding their selection procedures, the groups showed no difference. All patients matching the above-mentioned criteria of presence of anti-Chlamydia-LPS antibodies during the period of this study were included in one of the groups.

The following assays were carried out in both groups:

1. Detection of IgA and IgG antibodies against chlamydial LPS by ELISA method ("Chlamydien-rELISA", medac, Wedel, Germany).

2. Detection of level of total immunoglobulins of $\mathrm{IgG} 2$ isotype by nephelometry using ARRAY 360 analyzer unit (Beckman Coulter, Fullerton, USA) and the "Human IgG2 Subclass Beckman ARRAY Kits" sets (The Binding Site, Birmingham, UK).

3. Detection of level of total immunoglobulins of $\operatorname{IgG}$ isotype (determined just in 43 of 44 patients of the control group), determined also by nephelometry using the identical analyzer unit and the "Immunoglobulin G Reagent, ARRAY Systems" sets (Beckman Coulter, Fullerton, USA).

Operating instructions as per individual manufacturer were followed during the assays and during the evaluation of results.

The measured values of total immunoglobulins of both classes were compared to the age-dependent laboratory standard values (Table 1$)^{9}$ and then the occurrences of decreased, standard and increased levels of total IgG2 and IgG in probands were compared to the controls $\left(\chi^{2}\right.$ test $)$.

\section{RESULTS}

None of the probands showed total IgG2 levels below standard values, while such decreased values were demonstrated in 1 subject $(2.3 \%)$ of the control group. Increased IgG2 levels were found in $12(35.3 \%)$ probands and in $15(34.1 \%)$ control patients. Consequently, standard values of IgG2 levels were demonstrated in $22(64.7 \%)$ probands and $28(63.6 \%)$ control patients.

Total IgG levels below standard values were found in $4(11.8 \%)$ probands and $5(11.4 \%)$ controls; increased total IgG levels were found in $2(5.9 \%)$ probands and $1(2.3 \%)$ patient of the control group. Consequently, standard total IgG levels occurred in $28(82.3 \%)$ probands and $37(86.3 \%)$ controls.

No statistically significant differences were found between the two groups in any of the categories monitored (i.e. decrease, increase, standard value), both for total IgG and total IgG2 (Table 2).

Table 1. Laboratory standard values of total $\operatorname{IgG} 2$ and $\operatorname{IgG}$ levels according to age9.

\begin{tabular}{|c|c|c|c|}
\hline & Upper age limit & \multicolumn{2}{|c|}{ standard value $(\mathrm{g} / \mathrm{L})$} \\
\hline & & men & women \\
\hline & 2 years & $0.215-4.4$ & $0.215-4.4$ \\
\hline & 4 years & $0.28-3.15$ & $0.28-3.15$ \\
\hline & 6 years & $0.565-3.45$ & $0.565-3.45$ \\
\hline & 8 years & $0.42-3.75$ & $0.42-3.75$ \\
\hline & 10 years & $0.61-4.3$ & $0.61-4.3$ \\
\hline & 12 years & $0.73-4.55$ & $0.73-4.55$ \\
\hline & 14 years & $0.71-4.6$ & $0.71-4.6$ \\
\hline & 18 years & $0.435-4.95$ & $1.435-4.95$ \\
\hline & 99 years & $1.235-5.487$ & \multicolumn{2}{|c|}{ both sexes } \\
\hline & & \multicolumn{2}{|c|}{$2.7-12.7$} \\
\hline & 15 days & \multicolumn{2}{|c|}{$5.6-11.2$} \\
\hline & 3 months & \multicolumn{2}{|c|}{$9.0-15.0$} \\
\hline & 12 months & \multicolumn{2}{|c|}{} \\
\hline & 15 years & 99 years & \multicolumn{2}{|c|}{} \\
\hline & &
\end{tabular}



against lipopolysaccharide of Chlamydia

Table 2. Evaluation of variations in the presence of decreased, standard and increased $\operatorname{IgG} 2$ and $\mathrm{IgG}$ levels in patients.

\begin{tabular}{|c|c|c|c|c|c|c|}
\hline & \multicolumn{3}{|c|}{ IgG2 } & \multicolumn{3}{c|}{ IgG } \\
\hline & $\mathrm{P}^{\mathrm{a}}(\mathrm{n}: 34)$ & $\mathrm{C}^{\mathrm{b}}(\mathrm{n}: 44)$ & $\chi^{2} / \mathrm{SS}^{\mathrm{c}}$ & $\mathrm{P}^{\mathrm{a}}(\mathrm{n}: 34)$ & $\mathrm{C}^{\mathrm{b}}(\mathrm{n}: 43)$ & $\chi^{2} / \mathrm{SS}^{\mathrm{c}}$ \\
\hline decreased & 0 & 1 & $2.273 /$ n.s. $^{\mathrm{d}}$ & 4 & 5 & $0.137 /$ n.s. $^{\mathrm{d}}$ \\
\hline standard & 22 & 28 & $1.07 /$ n.s. $^{\mathrm{d}}$ & 28 & 37 & $1.368 /$ n.s. $^{\mathrm{d}}$ \\
\hline increased & 12 & 15 & $1.203 /$ n.s. $^{\mathrm{d}}$ & 2 & 1 & $3.61 /$ n.s. $^{\mathrm{d}}$ \\
\hline
\end{tabular}

${ }^{\text {a }}$ probands

b controls

c statistical significance

d not significant

\section{DISCUSSION AND CONCLUSION}

Generally, formation of $\operatorname{IgG} 2$ subgroup of the $\mathrm{IgG}$ isotype can be expected during antibody immune response to the presence of polysaccharide antigens in the human body ${ }^{10}$. However, a statistically significant decrease in this particular subgroup in children with recurrent respiratory diseases has been also reported in literature ${ }^{11}$.

The increased total IgG2 levels in both the proband and control groups detected by us are in accordance with the assumption of accentuated formation of this particular IgG subgroup in subjects with demonstrated presence of antibodies against chlamydial LPS (in our particular case IgA alone and IgA plus IgG in probands and control patients, respectively).

However, our study has not confirmed the hypothesis that absence of anti-chlamydial LPS specific $\mathrm{IgG}$ is related to reduced formation of total $\mathrm{IgG} 2 / \mathrm{IgG}$. No statistically significant differences between both groups have been demonstrated. This finding supports the assumption of normal formation of specific anti-Chlamydia-LPS IgG. What follows is likely an immune complex bond, which hinders the antibodies to be detected by any of the methods we use. However, examples of the release of specific antibodies from the bond by breakage of immune complexes and their subsequent detection are known, e.g. from borrelial serology ${ }^{12,13}$. Since the monitoring of presence and dynamics of formation of specific IgG class antibodies can contribute to the improved diagnostics of the course and the activity/ chronicity of a chlamydial infection, it is desirable to determine the applicability of an analogous methodology. Should this prove successful, it will be possible to evaluate the clinical significance of detection of specific anti-Chlamydia antibodies bound in this way. Consequently, further research activities will be focused on the isolation of serous immune complexes and release of antibodies from the immune complex bond and subsequent detection of specific antibodies against chlamydial LPS.

\section{ACKNOWLEDGEMENT}

This investigation was supported by the Research project (Výzkumný záměr) MSM 151100002.

\section{REFERENCES}

1. Mazzoli S, Tofani, N, Fantini A, Semplici F, Bandini F, Salvi A, Vergassola R. (1998) Chlamydia pneumoniae antibody response in patients with acute myocardial infarction. Am Heart J 135, 15-20.

2. Sodja I, Bruj J, Švecová M, Kadlečík D, Mrázová M. (1998) Promořenost a úloha Chlamydia pneumoniae v etiologii respiračních onemocnění v České republice. Epidemiol Mikrobiol Imunol 47, 27-31.

3. Žampachová E. (1998) Diagnostika infekcí způsobených Chlamydia trachomatis. Souhrn více než desetiletých zkušeností. Remedia Klin Mikrobiol 2, 75-8.

4. Verkooyen RP, Van Lent NA, Mousavi Joulandan SA, Snijder RJ, Van den Bosch JM, Van Helden HP, Verbrugh HA. (1997) Diagnosis of Chlamydia pneumoniae infection in patients with chronic obstructive pulmonary disease by micro-immunofluorescence and ELISA. J Med Microbiol 46, 959-64.

5. Žampachová E. (1998) Chlamydia pneumoniae jako původce respiračních infekcí. Klin Mikrobiol Inf Lék 4, 54-6.

6. Verkooyen RP. (1997) Chlamydia pneumoniae: studies on an emerging pathogen. CIP-Gegevens Koninklijke Bibliotheek, Den Haag.

7. Pospíssil L, Věžník Z, Diblíková I. (1998) Prevalence chlamydiové infekce u osob z exponovaného prostředí. Remedia Klin Mikrobiol 2, 83-6.

8. Hejnar P, Krátká J. (2000) Prävalenz von IgA-, IgG- und IgMAntikörpern gegen Chlamydien mit Hilfe von rekombinanten ELISA-Testen von medac bei Patienten der Universitätsklinik Olomouc und Bedeutung des IgM-Nachweises für die Diagnostik aktiver Infektionen. Mikrobiologe 10, 209-12.

9. Wágner P. (2000) Laboratorní referenční hodnoty 2000/2001. Triton, Praha.

10. Fučíková T. (1997) Klinická imunologie v praxi. Galén, Praha.

11. Kapellerová A, Kasanická A, Ponec J, Vasilenková A, Cingelová D, Kuková Z. (1993) Podtriedy IgG u detí s recidivujúcimi respiračními chorobami. Čs Pediatrie 48, 697-700.

12. Pícha D, Moravcová L, Skalská S, Lásiková Š, Hančil J, Roháčová H, Patakiová E. (2000) Klinický význam průkazu specifických antiboreliových protilátek vázaných $\mathrm{v}$ cirkulujících imunitních komplexech $\mathrm{u}$ pacientů s lymeskou boreliózou. Klin Mikrobiol Inf Lék 4, 108-11.

13. Schutzer SE, Coyle PK, Reid P, Holland B. (1999) Borrelia burgdorferi - specific immune complexes in acute Lyme disease. JAMA 282, 1942-6. 